\title{
PERBEDAAN HARGA DIRI REMAJA DITINJAU DARI STATUS KELUARGA PADA SMA AL - ULUM MEDAN
}

\author{
Istiana, S.Psi, M.Pd, M.Psi \\ Fakultas Psikologi \\ Universitas Medan Area
}

\begin{abstract}
Abstrak
Penelitian ini bertujuan untuk melihat perbedaan harga diri remaja yang memiliki status keluarga broken home dan tidak broken home. Penelitian ini menggunakan metode penelitian kuantitatif, subjek penelitian adalah remaja pada siswa SMA Swasta Al-Ulum Medan, usia 15 - 18 tahun, status keluarga broken home dan tidak broken home. Jumlah sampel dalam penelitian ini sebanyak 70 orang siswa, sebanyak 35 orang sampel yang dari keluarga broken home dan 35 orang sampel yang dari keluarga tidak broken home. Teknik pengambilan data yang digunakan dalam penelitian ini, menggunakan purposive sampling. Dengan melihat nilai rata-rata diketahui bahwa remaja yang memiliki status keluarga yang tidak broken home memiliki harga diri yang tinggi dengan nilai rata-rata 94,200 dibandingkan remaja yang memiliki status keluarga yang broken home memiliki harga diri yang rendah dengan nilai rata-rata 80,400. Hasil penelitian ini diketahui dengan melihat nilai atau koefisien perbedaan dari anava satu jalur dengan koefisien $\mathrm{F}=19426$ dengan $\mathrm{p}=$ $0.000,<0,010$. Berdasarkan hasil ini maka hipotesis yang diajukan yang berbunyi ada perbedaan harga diri remaja ditinjau dari status keluarga pada SMA Swasta Al-Ulum Medan, dinyatakan diterima.
\end{abstract}

Kata Kunci : Harga Diri, Remaja, Status Keluarga

\section{PENDAHULUAN}

Pada masa remaja, seorang anak akan mengalami berbagai perubahan dan permasalahan di dalam kehidupannya terutama di dalam harga diri (self esteem). Remaja akan merasa kurang diberi kesempatan untuk mengekspresikan diri, karena itu sikap remaja dipengaruhi adanya harga diri.

Menurut Santrock (2005), harga diri adalah evaluasi individu terhadap dirinya sendiri secara rendah atau tinggi. Penilaian tersebut terlihat dari penghargaan mereka terhadap keberadaan dan keberartian dirinya. Individu yang memiliki harga diri yang tinggi akan menerima dan menghargai dirinya sendiri apa adanya. Sedangkan individu yang memiliki harga diri yang rendah akan cenderung cemas menghadapi hidupnya, dan cenderung kurang berani mengambil resiko. Dalam harga diri tercakup evaluasi dan penghargaan terhadap diri sendiri dan menghasilkan penilaian tinggi atau rendah terhadap dirinya sendiri. Penilaian tinggi terhadap diri sendiri adalah penilaian terhadap kondisi diri, menghargai kelebihan dan potensi diri, serta menerima kekurangan yang ada, sedangkan yang dimaksud dengan penilaian rendah terhadap diri sendiri adalah penilaian tidak suka atau tidak puas dengan kondisi diri sendiri, tidak menghargai kelebihan diri 
dengan melihat diri sebagai sesuatu yang selalu kurang.

Fenomena yang terjadi di sekolah SMA Al-Ulum menunjukkan bahwa siswa yang memiliki harga diri rendah disebabkan oleh lingkungan keluarga yang broken home ditunjukkan dengan perilaku anak yang menjadi pemberontak dan mudah marah, menjadi kurang percaya diri karena merasa tidak dihargai sebelumnya di dalam keluarga, serta kurang bersemangat dan kurang motivasi dari keluarga dibandingkan dengan siswa yang memiliki keluarga yang tidak broken home.

Harga diri yang didukung oleh penghargaan pada dirinya sendiri akan membuat seseorang percaya diri, mampu menerima kritik yang baik, dan merasa mempunyai keyakinan akan kemampuan untuk mengatasi masalah dalam kehidupan. Walaupun banyak hal yang dapat mempengaruhi harga diri seseorang namun apabila harga diri tidak didukung akan penghargaan diri sendiri akan membuat individu cenderung tidak percaya diri, cemas menghadapi hidupnya, dan merasa rendah diri ketika sedang berhadapan dengan orang lain.

Salah satu faktor yang mempengaruhi harga diri remaja adalah lingkungan keluarga. Keluarga adalah lembaga pertama dan utama dalam melaksanakan proses sosialisasi dan pendidikan pada anak. Bersama keluarga anak belajar mengenal cinta kasih, simpati, bimbingan, dan pendidikan. Keluarga memberikan pengaruh dalam menentukan pembentukan watak dan kepribadian anak, menjadi unit sosial terkecil yang memberi pondasi primer bagi perkembangan anak serta merupakan tempat sosialisasi pertama bagi anak.

Lingkungan keluarga yang harmonis dapat memberikan kenyamanan, kedamaian, serta kesejahteraan bagi anak, sedangkan kondisi keluarga yang tidak harmonis dan tidak berjalan layaknya keluarga yang rukun, damai, dan sejahtera disebabkan karena sering terjadi keributan serta perselisihan yang menyebabkan pertengkaran dan berakhir pada perceraian. Keadaan rumah tangga yang berantakan dapat membawa pengaruh psikologis buruk bagi perkembangan mental dan pendidikan anak. Dasar pribadi anak terutama dibentuk dalam lingkungan keluarga. Jika kehilangan keharmonisan di dalam keluarga seperti kehilangan salah satu dari kedua orang tua atau kehilangan keduanya disebabkan karena meninggal ataupun bercerai, dan lain-lainnya, dapat menyebabkan anak kehilangan contoh model orang dewasa. 
Kehilangan kasih sayang, kehilangan pendidik atau pembimbing yang sangat ia butuhkan.

Dalam penelitian ini, peneliti meninjau dari terjadinya konflik-konflik yang menyebabkan penderitaan terutama pada anak. Bagi anak yang broken home tentu akan memberi dampak negatif bagi perilakunya terutama yang berkaitan dengan harga diri. Adanya dampak negatif yang begitu besar pada kasus ini adalah harga diri rendah yang dapat mengakibatkan kecemasan yang berlebihan, individu akan takut ditolak, dan takut gagal. Cenderung cemas menghadapi hidupnya, dan cenderung kurang berani mengambil resiko, merasa rendah diri, ketika berhadapan dengan orang lain.

Individu cenderung menarik diri dan dampak yang berbahaya bagi individu juga adanya keinginan untuk menciderai dirinya sendiri, karena rendahnya harga diri yang dimiliki individu tersebut. Dalam kehidupan dan perkembangan remaja, peran keluarga sangat penting terutama di dalam meningkatkan harga diri anak remaja. Namun sekarang ini, terjadi banyak permasalahan di dalam keluarga dan salah satunya adalah broken home.
Menurut Willis (2003), broken home adalah kurangnya perhatian dari keluarga atau kurangnya kasih sayang orang tua sehingga membuat mental anak menjadi frustasi, brutal, dan susah diatur. Selain itu, istilah broken home juga digunakan untuk menggambarkan keluarga yang tidak harmonis dan tidak berjalan layaknya keluarga yang rukun dan sejahtera akibat seringnya terjadi konflik yang menyebabkan perpisahan (perceraian). Kondisi broken home akan ada kemungkinan besar terjadinya kenakalan remaja, terutama perceraian atau perpisahan orang tua yang akan mempengaruhi perkembangan si anak.

Keadaan yang tidak normal bukan hanya terjadi pada broken home, akan tetapi dalam masyarakat modern sering pula terjadi suatu gejala adanya "broken home semu" atau quasi broken home, yaitu kondisi dimana kedua orang tuanya masing utuh, tetapi karena masing-masing anggota keluarga (ayah dan ibu) mempunyai kesibukan masing-masing sehingga orang tua tidak sempat memberikan perhatian yang cukup terhadap pendidikan anak-anaknya.

Dalam situasi keluarga yang broken home demikian anak mengalami frustasi, merasa rendah diri ketika berhadapan dengan orang lain, serta juga mengalami 
konflik-konflik psikologis. Keharmonisan keluarga mempuyai peranan yang sangat dominan dalam pembentukan kepribadian anak. Kenyataannya kondisi keluarga broken home sering sulit dihindarkan ketika konflik dalam rumah tangga terjadi. Fenomena yang muncul kepercayaan diri terhadap keluarga akan menyebabkan menurunnya harga diri remaja dibandingkan dengan remaja yang tidak mengalami broken home.

Peneliti membatasi masalah mengenai perbedaan harga diri remaja ditinjau dari keluarga broken home dan tidak broken home. Didalam penelitian ini, peneliti menjelaskan variabel harga diri. Harga diri adalah penilaian pribadi terhadap hasil yang dicapai dengan menganalisis seberapa banyak kesesuaian tingkah laku dengan ideal dirinya. Peneliti juga membatasi penelitian pada anak remaja yang di keluarga yang broken home dan tidak broken home.

Rumusan permasalahan penelitian ini adalah: "Apakah ada perbedaan harga diri remaja broken home dan tidak broken home?"

Tujuan dari penelitian ini adalah untuk mengetahui perbedaan harga diri seorang remaja yang berasal dari keluarga broken home dan tidak broken home.

\section{KAJIAN PUSTAKA}

\section{Remaja}

Menurut Hurlock (2003), masa remaja adalah masa peralihan dimana perubahan fisik dan psikologis dari masa kanak-kanak ke masa dewasa. Perubahan psikologis yang terjadi pada masa remaja meliputi intelektual, kehidupan emosi, dan kehidupan sosial. Perubahan fisik mencakup organ seksual yaitu alat-alat reproduksi sudah mencapai kematangan dan mulai berfungsi dengan baik. Menurut Sri \& Sundari (2004), masa remaja adalah peralihan dari masa anak dengan masa dewasa yang mengalami perkembangan semua aspek atau fungsi untuk memasuki masa dewasa. Sementara Muagman (dalam Sarwono, 2006) mendefenisikan remaja berdasarkan defenisi konseptual World Health Organization (WHO) yang mendefenisikan remaja berdasarkan tiga kriteria, yaitu biologis, psikologis, sosial ekonomi.

Sarwono (2010), mengemukakan bahwa dalam proses penyesuaian diri menuju kedewasaan, ada tiga tahap perkembangan remaja :

1. Remaja awal (12 tahun-15 tahun)

Seorang remaja pada tahap ini masih terheran-heran akan perubahanperubahan yang terjadi pada tubuhnya sendiri dan dorongan- dorongan yang 
menyertai perubahan-perubahan itu. Mereka mengembangkan pikiranpikiran baru, cepat tertarik pada lawan jenis, dan mudah terangsang secara erotis. Dengan dipegang bahunya saja oleh lawan jenis ia sudah berfantasi erotik. Kepekaan yang berlebih-lebihan ini ditambah dengan berkurangnya kendali terhadap ego menyebabkan para remaja awal ini sulit dimengerti orang dewasa.

2. Remaja madya (15 tahun-18 tahun)

Pada tahap ini remaja sangat membutuhkan kawan-kawan. Seorang remaja senang kalau banyak teman yang mengakuinya. Ada kecenderungan narsistis yaitu mencintai diri sendiri, dengan menyukai teman-teman yang sama dengan dirinya. Ia berada dalam kondisi kebingungan karena tidak tahu memilih yang mana peka atau tidak peduli, ramai-ramai atau sendiri, optimistis atau pesimistis, idealis atau materialis, dan sebagainya.

3. Remaja akhir (19 tahun-22 tahun)

Masa ini ditandai oleh persiapan akhir untuk memasuki peran-peran orang dewasa. Selama periode ini remaja berusaha memantapkan tujuan vokasional dan mengembangkan identitas diri (sense of personal identity. Keinginan yang kuat untuk menjadi matang dan diterima dalam kelompok teman sebaya dan orang dewasa.

\section{Harga Diri}

Menurut Santrock (2005), harga diri adalah evaluasi individu terhadap dirinya sendiri secara rendah atau tinggi. Penilaian tersebut terlihat dari penghargaan mereka terhadap keberadaan dan keberartian dirinya. Individu yang memiliki harga diri yang tinggi akan menerima dan menghargai dirinya sendiri apa adanya. Dalam harga diri tercakup evaluasi dan penghargaan terhadap diri sendiri dan menghasilkan penilaian tinggi atau rendah terhadap dirinya sendiri. Penilaian tinggi terhadap diri sendiri adalah penilaian terhadap kondisi diri, menghargai kelebihan dan potensi diri, serta menerima kekurangan yang ada, sedangkan yang dimaksud dengan penilaian rendah terhadap diri sendiri adalah penilaian tidak suka atau tidak puas dengan kondisi diri sendiri, tidak menghargai kelebihan diri dengan melihat diri sebagai sesuatu yang selalu kurang.

Menurut Robinson (dalam Aditomo \& Retnowati, 2004) harga diri merupakan salah satu komponen yang lebih spesifik dari konsep diri, yang melibatkan unsur evaluasi atau penilaian terhadap diri. 
Menurut Branden (2000), harga diri adalah perpaduan antara kepercayaan diri (self-confidence) dengan penghormatan diri (self-respect). Harga diri menggambarkan keputusan seseorang secara implisit atas kemampuannya dalam mengatasi tantangan-tantangan kehidupan (untuk memahami dan menguasai masalah-masalah yang ada) dan hak seseorang untuk menikmati kebahagiaan.

Monks (2004), menyebutkan bahwa terdapat empat faktor yang mempengaruhi harga diri seseorang, diantaranya:

1. Lingkungan keluarga

Lingkungan keluarga merupakan tempat sosialisasi pertama bagi anak.Perlakuan adil dari orang tua, pemberian kesempatan untuk aktif dan pendidikan yang demokratis di dapat pada anak yang memiliki harga diri yang tinggi.

2. Lingkungan sosial

Lingkungan sosial tempat individu mempengaruhi bagi pembentukan harga diri.Individu mulai menyadari bahwa dirinya berharga sebagai individu dengan lingkungannya. Kehilangan kasih sayang, penghinaan, dan dijauhi teman sebayaakan menurunkan harga diri. Sebaliknya pengalaman, keberhasilan, persahabatan, dan kemasyuran akan meningkatkan harga diri.

3. Faktor psikologis

Penerimaan diri akan mengarahkan individu mampu menentukan arah dirinya pada saat mulai memasuki hidup bermasyarakat sebagai anggota masyarakat yang sudah dewasa.

4. Jenis kelamin

Perbedaan jenis kelamin mengakibatkan terjadinya perbedaan dalam pola pikir, cara berpikir, dan bertindak antara laki-laki dan perempuan. Menurut Harter (dalam Santrock, 2005) percaya bahwa intervensi seharusnya muncul pada tingkat penyebab harga diri apabila harga diri remaja meningkat secara signifikan. Remaja memiliki harga diri lebih tinggi ketika mereka menampilkan secara kompeten pada bagian-bagian penting untuk diri

Menurut felker (dalam saidi, 2009) terdapat tiga aspek yang berhubungan dengan harga diri (self-esteem), yaitu:

1. Perasaan disertakan atau diterima (feeling of belonging)

2. Perasaan mampu (feeling of competence)

3. Perasaan berharga (feeling of worth)

Sementara menurut Sudarsono (2004) aspek - aspek harga diri, meliputi : 
1. Keberartian Diri (Significance)

2. Kekuatan Individu (Power)

3. Kompetensi (Competence)

Harga diri dapat dipisahkan pada karakteristik harga diri yang tinggi dan rendah menurut Dariuszky (dalam Linda, 2012) antara lain :

1. Karakteristik yang memiliki harga diri yang tinggi :

a. Pada umumnya, tidak terlalu khawatir akan keselamatan hidupnya dan lebih menghadapi resiko.

b. Bersedia mempertanggung jawabkan kegagalan maupun kesalahan

c. Cenderung melakukan aktivitasaktivitas yang bertujuan memperbaiki atau menyempurnakan dirinya.

d. Mempunyai harapan positif dan memilki perasaan yang positif.

e. Jauh lebih tegar ketika sedang mengalami kemalangan atau kesusahan, dan cenderung merasa puas dengan isi pikiran dan perbuatannya.

Harga diri yang tinggi ditandai dengan adanya keyakinan yang kukuh, kebebasan, emosi positif, kegairahan dan semangat hidup yang positif.

2. Karakteristik yang memilki harga diri yang rendah

a. Sulit menemukan hal-hal positif dalam tindakan yang mereka lakukan, yang sebenarnya mereka mampu untuk melakukannya.

b. Cenderung cemas menghadapi hidupnya, dan cenderung kurang berani mengambil resiko.

c. Merasa rendah diri, ketika berhadapan dengan orang lain.

d. Pikiran cenderung mudah terserang perasaan depresi, putus asa, dan adanya niat untuk bunuh diri.

\section{Keluarga}

Menurut Soerjani (2000), keluarga adalah lembaga pertama dan utama dalam melaksanakan proses sosialisasi dan pendidikan pada anak. Dalam keluarga anak belajar mengenal makan, cinta kasih, simpati, bimbingan dan pendidikan. Keluarga memberikan pengaruh menentukan padapembentukan watak dan kepribadian anak dan menjadi unit sosial terkecil yang memberipondasi primer bagi perkembangan anak. Keluarga adalah rumah tangga yang memiliki hubungan darah atau perkawinan atau menyediakan terselenggaranya fungsi-fungsi instrumental mendasar dan fungsi-fungsi ekspresif keluarga bagi para anggotanya yang berada dalam suatu keluarga.

Menurut Ali (2010), ciri-ciri keluarga adalah: 
1. Mempunyai ikatan keluarga yang sangat erat yang dilandasi oleh semangat kegotong-royongan.

2. Merupakan satu kesatuan utuh yang dijiwai oleh nilai budaya ketimuran yang kental yang mempunyai tanggung jawab besar.

3. Umumnya dipimpin oleh suami sebagai kepala rumah tangga yang dominan dalam mengambil keputusan walaupun prosesnya melalui musyawarah dan mufakat.

4. Sedikit berbeda antara yang tinggal di pedesaan dan di perkotaan. Keluarga di pedesaan masih bersifat tradisional, sederhana, saling menghormati satu sama lain dan sedikit sulit menerima inovasi baru.

Menurut Friedman (dalam Sudiharto, 2007) ada lima fungsi dasar keluarga adalah sebagai berikut:

1. Fungsi afektif, adalah fungsi internal keluarga untuk pemenuhan kebutuhan psikososial, saling mengasuh dan memberikan cinta kasih serta, saling menerima dan mendukung

2. Fungsi sosialisasi, adalah proses perkembangan dan perubahan individu keluarga, tempat anggota keluarga berinteraksi sosial dan belajar berperan di lingkungan social
3. Fungsi reproduksi, adalah fungsi keluarga meneruskan kelangsungan keturunan dan menambah sumber daya manusia

4. Fungsi ekonomi, adalah fungsi keluarga untuk memenuhi kebutuhan keluarga, seperti sandang, pangan, dan papan

5. Fungsi perawatan kesehatan, adalah kemampuan keluarga untuk merawat anggota keluarga yang mengalami masalah kesehatan.

Menurut Friedman (2010), tugas pokok keluarga diantaranya:

1. Pemeliharaan fisik keluarga dan para anggotanya

2. Pemeliharaan sumber - sumber daya yang ada dalam keluarga.

3. Pembagian tugas masing - masing anggotanya sesuai dengan kedudukannya

4. Sosialisasi antar anggota keluarga.

5. Pengaturan jumlah anggota keluarga.

6. Pemeliharaan ketertiban anggota keluarga.

7. Membangkitkan dorongan dan semangat pada anggota keluarga.

Berbagai peranan yang terdapat di dalam keluarga yakni :

1. Ayah sebagai suami dari istri dan ayah bagi anak - anak, berperan sebagai pencari nafkah, pendidik, pelindung 
dan pemberi rasa aman, sebagai kepala keluarga, sebagai anggota dari kelompok sosialnya serta sebagai anggota masyarakat dari lingkunganya.

2. Ibu sebagai istri dan ibu dari anak anaknya, ibu mempunyai peranan untuk mengurus rumah tangga, sebagai pengasuh dan pendidik bagi anak anaknya, pelindung dan sebagai salah satu kelompok dari peranan sosial serta sebagai anggota masyarakat di lingkungannya, disamping itu juga ibu perperan sebagai pencari nafkah tambahan dalam keluarganya.

3. Peran anak yang utama adalah membantu meringankan beban/pekerjaan orang tua. Misalnya belajar yang rajin tanpa harus disuruh.dan melaksanakan peranan psikososial sesuai dengan tingkat perkembangannya baik fisik, mental, sosial, dan spiritual.

Dalam kehidupan dan perkembangan anak, peran keluarga sangat memiliki peran penting terutama didalam meningkatkan harga diri seorang anak remaja.Namun sekarang ini, terjadi banyak permasalahan didalam keluarga dan salah satunya adalah broken home. Broken home diartikan dengan kondisi keluarga yang tidak harmonis dan tidak berjalan layaknya keluarga yang rukun, damai, dan sejahtera karena sering terjadi keributan serta perselisihan yang menyebabkan pertengkaran dan berakhir pada perceraian, yang dimaksud keluarga pecah (broken home) dapat dilihat dari dua aspek:

1. Keluarga itu terpecah karena strukturnya tidak utuh sebab salah satu dari kepala keluarga itu meninggal atau telah bercerai.

2. Orang tua tidak bercerai akan tetapi struktur keluarga itu tidak utuh lagi karena ayah atau ibu sering tidak dirumah, dan atau tidak memperlihatkan hubungan kasih sayang lagi.

Menurut Blair dan Joner (dalam Willis, S. Sofyan, 2009) ciri-ciri keluarga broken home adalah :

1. Sering berdebat dan tidak ada rasa hormat

2. Kurangnya kasih sayang

3. Depresi dan kesepian

4. Tidak menghabiskan waktu dengan keluarga

5. Bahasa tubuh

\section{METODE PENELITIAN}

Metode yang digunakan dalam penelitian ini adalah pendekatan kuantitatif.

Populasi dalam penelitian adalah siswa yang ada di SMA Al-Ulum Medan 
yang memiliki jumlah siswa 655 orang. Peneliti menggunakan $10 \%$ dari jumlah populasi sehingga dari persentase tersebut diperoleh sampel subjek sebanyak 70 orang. Dari kelas I didapat sampel siswa yang berasal dari keluarga broken home sebanyak 18 orang, sedangkan dari kelas II di dapat sampel siswa yang berasal dari keluarga broken home sebanyak 17 orang. Jumlah keseluruhan sample didapatkan berdasarkan screening (pemilahan) yang telah dilakukan kepada siswa. Pengambilan sampel dilakukan secara purposive sampling dengan ciri- ciri sebagai berikut :

1. Merupakan anak remaja madya/tengah (usia 15 - 18 tahun)

2. Merupakan remaja yang berasal dari keluarga broken home

3. Merupakan remaja yang berasal dari keluarga tidak broken home

Hingga didapatkan jumlah siswa yang mengalami atau berasal dari keluarga broken home sebanyak 35 orang dan siswa yang berasal dari keluarga yang tidak broken home sebanyak 35 orang.

Data yang dikumpulkan untuk penelitian menggunakan data primer, yaitu data yang diperoleh secara langsung ke lapangan guna mendapatkan data yang lengkap dan relevan dengan kompleks penelitian. Berdasarkan data-data yang ada baru dapat dilakukan hasil-hasil penelitian dan penelitian ini dilakukan dengan menggunakan metode skala. Skala yang dipakai adalah skala harga diri skala dalam disusun dalam bentuk skala Likert dengan 4 alternatif jawaban untuk item yang bersifat Favourable dan Unfavourable.

\section{Metode Analisis Data}

Metode analisis data yang digunakan adalah analisis varians 1 jalur, dalam penelitian ini yang menjadi jalurnya adalah status keluarga, yakni keluarga broken home (A1) dan keluarga tidak broken home (A2). Selanjutnya status keluarga ini disebut variabel bebas $(\mathrm{X})$, sedangkan variabel yang akan diukur atau variable terikatnya (Y) adalah harga diri. Berikut adalah bagan penelitian Analisis Varians 1 Jalur:

\begin{tabular}{|c|c|}
\hline \multicolumn{2}{|c|}{$\mathrm{A}$} \\
\hline $\mathrm{A} 1$ & $\mathrm{~A} 2$ \\
\hline $\mathrm{X}$ & $\mathrm{X}$ \\
\hline
\end{tabular}

Keterangan :

$$
\begin{array}{ll}
\text { A } & =\text { Status keluarga } \\
\text { A } 1 & =\text { Keluarga broken home } \\
\text { A } 2 & =\text { Keluarga tidak broken home } \\
\text { X } & =\text { Harga diri }
\end{array}
$$$$
\text { HASIL DAN PEMBAHASAN }
$$

1. Uji Asumsi

a. Uji Normalitas Sebaran

Tabel 1. Rangkuman Hasil perhitungan Uji Normalitas Sebaran

\begin{tabular}{|c|c|c|c|c|c|}
\hline $\begin{array}{c}\text { Variab } \\
\text { el }\end{array}$ & Rerata & SD & K-S & $\mathbf{P}$ & $\begin{array}{c}\text { Keter } \\
\text { anga } \\
\mathbf{n}\end{array}$ \\
\hline $\begin{array}{c}\text { Harga } \\
\text { diri }\end{array}$ & 144.593 & $\begin{array}{c}18.9 \\
67\end{array}$ & $\begin{array}{c}0,85 \\
2\end{array}$ & $\begin{array}{c}0,46 \\
2\end{array}$ & $\begin{array}{c}\text { Norm } \\
\text { al }\end{array}$ \\
\hline
\end{tabular}


Keterangan :

RERATA = Nilai rata-rata

$\mathrm{Chi}^{2}=$ HargaKolmogorv-Smirnov

SD $\quad=$ Standard Deviasi

$\mathrm{p} \quad=$ Peluang Terjadinya Kesalahan

\section{b. Uji Homogenitas Varians}

Berdasarkan uji homogenitas varians diketahui bahwa subjek penelitian berasal dari sampel yang homogen. Sebagai kriterianya apabila $\mathrm{p}$ beda $>0,050$ maka dinyatakan homogen (Nisfiannoor, 2009).

Tabel 2. Rangkuman Hasil Perhitungan Uji Homogenitas Varians

\begin{tabular}{|c|c|c|c|c|}
\hline $\begin{array}{c}\text { Vari } \\
\text { abel }\end{array}$ & $\begin{array}{c}\text { Uji } \\
\text { Homogenitas }\end{array}$ & Koef & P & Ket \\
\hline $\begin{array}{c}\text { Harg } \\
\text { a diri }\end{array}$ & Levene Test & 6.613 & 0,05 & $\begin{array}{c}\text { Hom } \\
\text { ogen }\end{array}$ \\
\hline
\end{tabular}

2. Hasil Perhitungan Analisis Varians

Berdasarkan hasil perhitungan dari Anava satu jalur, diketahui terdapat perbedaan Harga Diri ditinjau dari anak broken home dan tidak broken home,. Hasil ini diketahui dengan melihat nilai atau koefisien perbedaan dari anava dengan koefisien $\mathrm{F}=19.426$ dengan $\mathrm{p}=$ $0.000,<0,010$. Berdasarkan hasil ini berarti hipotesis yang diajukan yang berbunyia ada perbedaan Harga Diri ditinjau dari anak broken home dan tidak broken home, dinyatakan diterima.

Tabel 3.Rangkuman Hasil Analisis Varians 1

\begin{tabular}{|c|c|c|c|c|c|c|}
\hline \multicolumn{7}{|c|}{ Jalur } \\
\hline 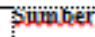 & $J \mathrm{~K}$ & DE" & " KK" & $F$ & $\mathrm{r}$ & $\mathrm{KE}$ \\
\hline $\begin{array}{l}\text { Betwen } \\
\text { Groups }\end{array}$ & 3332.700 & 1 & 3332700 & 19426 & 0.000 & S \\
\hline $\begin{array}{l}\text { Within } \\
\text { Groups }\end{array}$ & 11666000 & 68 & 171559 & - & - & - \\
\hline Total & 14995.700 & 69 & - & - & $=$ & - \\
\hline
\end{tabular}

Keterangan :

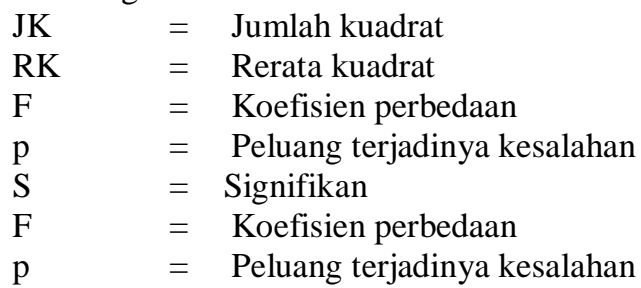

3. Hasil Perhitungan Mean

\section{Hipotetik dan Mean Empirik}

\section{a. Mean Hipotetik}

Variabel Harga Diri dalam penelitian ini diungkap dengan menggunakan skala yang berjumlah 32 butir dan diformat menggunakan skala Likert dengan 4 pilihan jawaban, maka mean hipotetiknya adalah $\left\{\left(\begin{array}{lll}31 & X & 1\end{array}\right)+\right.$ $(31 X 4\} / 2=77,500$

\section{b. Mean Empirik}

Berdasarkan analisis data, diketahui bahwa, mean empiric variable Harga Diri secara total adalah 87.300 , sebesar 90 Harga Diri Remaja Broken Home. 80.400 Harga Diri Remaja Tidak Broken Home sebesar 94.200.

\section{c. Kriteria}

Dalam upaya mengetahui kondisi harga diri, maka perlu dibandingkan antara mean/nilai rata-rata empirik dengan mean/nilai rata-rata hipotetik dengan memperhatikan besarnya bilangan SB atau SD dari variabel yang sedang diukur. Nilai SB atau SD variable Harga Diri secara total adalah sebesar 14.743, Harga Diri Remaja Broken Home sebesar 15.937, Harga Diri Remaja Tidak Broken 
Home sebesar 9.439. Jadi apabila mean/nilai rata-rata hipotetik $<$ mean/nilai rata-rata empirik, dimana selisihnya melebih ibilangan satu SB/SD, maka dinyatakan bahwa kelompok subjek penelitian memiliki Harga Diri yang tinggi dan apabila mean/nilai rata-rata hipotetik> mean/nilai rata-rata empirik, dimana selisihnya melebihi bilangan satuSimpangan Baku/Standar Deviasi, maka dinyatakan bahwa subjek penelitian memiliki Harga Diri yang rendah. Selanjutnya apabila mean/nilai rata-rata empiric tidak berbeda (tidak melebihi bilangan SD atau SB) dengan mean/nilai rata-rata hipotetiknya, maka harga diri dinyatakan sedang.

Tabel 4. Hasil Perhitungan Nilai Rata-rata Hipotetik dan Nilai Rata-rata Empirik

\begin{tabular}{|c|c|c|c|c|}
\hline \multirow[t]{2}{*}{ VARIABII } & \multicolumn{2}{|c|}{ Nilaikata-Kata } & \multirow[t]{2}{*}{ SD/SB } & \multirow[t]{2}{*}{ KETERANGAN } \\
\hline & Hipoteis & Expipis: & & \\
\hline Harga diri & 77500 & 87300 & 14.743 & Harga diai \\
\hline $\begin{array}{c}\text { Harga Diri Renaja } \\
\text { Broken Home }\end{array}$ & 77500 & 80.400 & 15937 & $\begin{array}{c}\text { Harga Diri Renaja } \\
\text { Broken Home }\end{array}$ \\
\hline $\begin{array}{l}\text { Harga Diri Renaja } \\
\text { Iidak Broken Home }\end{array}$ & 77500 & 94200 & 9.439 & $\begin{array}{c}\text { Harga Diri Bemaja I wat5 } \\
\text { Broken Home }\end{array}$ \\
\hline
\end{tabular}

Berdasarkan hasil perhitungan analisis varians 1 jalur menunjukkan bahwa terdapat perbedaan harga diri yang sangat signifikan antara remaja yang memiliki status keluarga broken home dan remaja yang memiliki status keluarga yang tidak broken home. Hasil ini diketahui dengan melihat nilai atau koefisien perbedaan dari anava dengan koefisien $\mathrm{F}=19.426$ dengan $\mathrm{p}=0.000$, <
0,010. Berdasarkan hasil ini berarti hipotesis yang diajukan yang berbunyi ada perbedaan harga diri ditinjau dari anak broken home dan tidak broken home, dinyatakan diterima.

Selanjutnya dengan melihat nilai rata-rata diketahui bahwa remaja yang memiliki status keluarga yang tidak broken home memiliki harga diri yang tinggi dengan nilai rata-rata 94.200 dibandingkan remaja yang memiliki status keluarga yang broken home memiliki harga diri yang rendah dengan nilai ratarata 80.400 .

Berdasarkan hasil penelitian ini diketahui remaja yang memiliki status keluarga yang tidak broken home, memiliki harga diri yang lebih tinggi dan positif jika dibandingkan dengan remaja yang memiliki status keluarga yang broken home, memiliki harga diri yang rendah.

Hasil penelitian ini sejalan dengan pendapat yang dikemukakan Burns (dalam Stevanus, 2003) menyatakan harga diri merupakan sekumpulan sikap individu dalam memandang dirinya, dalam hal ini dapat bersifat positif dan dapat pula bersifat negatif. Harga diri yang positif dapat membangkitkan rasa percaya diri, rasa yakin akan kemampuan diri, rasa berguna serta rasadiperlukan 
kehadirannya sebagai individu di dunia ini, sedangkan harga diri yang negatif merupakan bentuk dari harga diri yang rendah yang dapat menyebabkan frustasi sehingga dapat menimbulkan putus asa, adanya perasaan sia-sia atau perasaan gagal serta kurang berdaya dalam menghadapi berbagai tuntutan.

Sementara menurut Monk, 2004 faktor yang dapat mempengaruhi harga diri seseorang. Salah satunya adalah lingkungan keluarga merupakan tempat sosialisasi pertama bagi anak. Perlakuan adil dari orang tua, pemberian kesempatan untuk aktif dan pendidikan yang demokratis di dapat pada anak yang memiliki harga diri yang tinggi. Sebaliknya apabila anak tidak mendapatkan perlakuan adil dari orang tua dan tidak adanya kesempatan untuk aktif maka di dapat pada anak yang memiliki harga diri yang rendah.

Hasil yang diperoleh dari penelitian ini menunjukkan bahwa harga diri remaja pada siswa SMA Swasta Al-Ulum Medan dengan status keluarganya tidak broken home berada pada kategori lebih tinggi, hal ini didukung mean empirik (94.200) selisihnya dengan mean hipotetik (77.500) berada dalam 1 jangkauan SD yakni 9.439, sedangkan harga diri remaja dengan status keluarganya broken home berada pada kategori sedang, hal ini didukung mean empirik (80.400) selisihnya dengan mean hipotetik (77.500) berada dalam 1 jangkauan SD yakni, 15.937.

Berdasarkan hasil penelitian ini dapat dinyatakan bahwa harga diri remaja pada siswa SMA Swasta Al-Ulum Medan dengan status keluarga broken home dan tidak broken home tergolong berbeda.

\section{PENUTUP}

Terdapat perbedaan yang signifikan perbedaan harga diri yang sangat signifikan antara remaja yang memiliki status keluarga broken home dan remaja yang memiliki status keluarga yang tidak broken home. Hasil ini diketahui dengan melihat nilai atau koefisien perbedaan dari anava dengan koefisien $\mathrm{F}=19426$ dengan $\mathrm{p}=0.000,<0,010$. Berdasarkan hasil ini berarti hipotesis yang diajukan yang berbunyi ada perbedaan harga diri ditinjau dari anak broken home dan tidak broken home, dinyatakan diterima.

Selanjutnya dengan melihat nilai rata-rata diketahui bahwa remaja yang memiliki status keluarga yang tidak broken home memiliki harga diri yang tinggi dengan nilai rata-rata 94,200 dibandingkan remaja yang memiliki status keluarga yang broken home memiliki 
harga diri yang rendah dengan nilai ratarata 80,400 .

Diketahui harga diri remaja pada siswa SMA Al-Ulum Medan, berada pada kategori sedang, sebab mean empirik $(87,300)$ tidak berbeda dengan mean hipotetik $(77,500)$. Artinya nilai rata-rata empirik (hasil penelitian) harga diri pada remaja tidak berbeda atau tidak melebihi dari pada nilai rata-rata hipotetiknya

\section{DAFTAR PUSTAKA}

Aditomo, A., dan Retnowati, S.(2004). Perfeksionis, harga Diri, dan Kecenderungan Depresi. Jurnal Psikologi, (27 desember 2014. 09:35 PM)

Ali, M., dan Asrori, M. (2010).Psikologi Remaja : Perkembangan Peserta Didik.

Ali, M. (2010).Psikologi Remaja. Jakarta : Bumi Aksara

Arikunto, S. (1990).Penelitian Suatu Pendekatan Praktis. Edisi Revisi. Jakarta : Bina Aksara.

Arikunto, S. (2010).Prosedur Penelitian. Edisi Revisi 2010. Jakarta : Rineka Cipta.

Azwar, S. (2003).Metode Penelitian. Yogyakarta : Pustaka Pelajar.

Hadi, S. (2004).Metodologi Reaserch. Yogyakarta : yayasan penerbit Psikologi UGM

Handayani, S. (2000).Buku Ajar Pelayanan Keluarga Berencana. Yogyakarta: Pustaka Rihama
Hurlock, E.B. (2003). Perkembangan Anak. Jakarta: Erlangga.

Ivadhias, Swastika. (2010). "Resiliensi Pada Remaja yang Mengalami Broken Home".Jurnal Psikologi Universitas Guna Darma.

Kenny, S. (2013). Hubungan antara harga diri dengan penerimaan diri orang tua yang memiliki anak tunagrahita.Skripsi (tidak diterbitkan) Fakultas Psikologi UMA.

Linda, L. (2012). Psikologi Suatu Pengantar Jilid 2. Jakarta : Erlangga

Monks. (2004). Psikologi Perkembangan: Pengantar dalam Berbagai Bagiannya. Yogyakarta: Gajah Mada University Press.

Nilva, R. (2012). Hubungan Antara Penerimaan Diri Dengan Harga Diri Orang Tua Dalam Menentukan Mahar Pada Masyarakat Aceh. Skripsi (tidak diterbitkan) Fakultas Psikologi UMA.

Notoatmodjo, S.(2007). Psikologi Perkembangan: Pengantar dalam Berbagai Bagiannya. Yogyakarta: Gadjah Mada University Press.

Saidi, R. (2009).Harga diri remaja yang bertempat tinggal di dalam lingkungan kompleks pelacuran dan di luar kompleks pelacuran. Jurnal Psikologi Universitas Gadjah Mada, Vol 2. Yogyakarta : Gadjah Mada University

Santrock, J. W. (2003). Life-Span Development: Perkembangan Masa Hidup. Jakarta: Erlangga 
Santrock, J. W. (2005). Adolescence: Perkembangan Remaja.(edisi keenam) Jakarta: Erlangga

Sarwono,S.W. (2006). Psikologi Remaja. Jakarta : Raja Grafindo Persada

Sarwono.S.W.

(2010).Psikologi

Remaja.(edisi revisi) Jakarta : PT. RajaGrafindo Persada

Sri, R., dan Sundari, S. (2004). Perkembangan Anak \& Remaja.Jakarta : Rineka Cipta.

Siti, S. (2004). Awal Mula Keluarga Broken Home.Jurnal Psikologi Universitas Gadjah Mada, Vol 5.Yogyakarta : Gadjah Mada University

Stevanus, S.B. (2003). Psikologi dan Pengembangan Diri.Jakarta : Erlangga

Sudiharto. (2007). Askep keluarga dengan pendekatan keperawatan transkultural. Jakarta: EGC

Sudarsono, K. (2004). Self Esteem dan perkembangan diri. Jakarta : Rineka Cipta

Sugiyono. 2009. Statistik Untuk Penelitian. Bandung : Alfabeta.

Suliswati. (2005). Konsep Dasar Keperawatan Jiwa.Jakarta : EGC

Willis. (2003). Remaja Dan Masalahnya.Jakarta : Alfabeta

Willis, Sofyan .(2004). Konseling Individual Teori dan Praktek. Bandung: Alfabeta
Willis, Sofyan. S. (2009). Konseling Keluarga ; Family Counseling. Bandung : Alfabeta 